Asian Journal of Energy Transformation and Conservation

2014 Vol. 1, No. 1, pp. 26-43

$\operatorname{ISSN}(e): 2409-4293$

$\operatorname{ISSN}(p): 2412-3390$

DOI: 10.18488/journal.81/2014.1.1/81.1.26.43

(C) 2014. Conscientia Beam. All Rights Reserved.

(1) cosshate

\title{
RAYLEIGH DISTRIBUTION-BASED MODEL FOR PREDICTION OF WIND ENERGY POTENTIAL OF CAMEROON
}

\author{
Afungchui David ${ }^{1}$ \\ ${ }^{\prime}$ University of Bamenda, Faculty of Sciences; Department of Physics, Bambili, NWR, Cameroon
}

\begin{abstract}
Modelling and prediction of wind characteristics are essential design inputs in the development of wind energy systems. This paper exploits the characteristics of the Rayleigh probability density function to analyse the wind potential of all the regions of the republic of Cameroon. In the procedure, the probability density (PD) curves of some representative towns of the ten regions of Cameroon are presented. These curves highlight the fraction of time for which some wind velocity $V$ prevails at the sites and the most frequent wind speed expected at these sites which coincide with the peak of the PD curves. We then proceed to calculate the power density of the sites, as well as the energy available for wind turbine extraction. We recommend the Savonius rotor for the regions of low wind speed based on its low cut-in speed of $1 \mathrm{~m} / \mathrm{s}$.
\end{abstract}

Keywords: Rayleigh distribution, Wind energy, Power density, Savonius rotor, Cut-in and cut-out wind speeds.

\section{List of Abbreviations Used}

c Weibull scale factor

k Weibull shape factor

$\mathrm{T}$ Time period in hours

\section{Greek Letters}

$\rho$ Air density $\mathrm{kg} / \mathrm{m}^{3}$

\section{Superscripts}

k Weibull shape factor

\section{Subscripts}

$P_{D}$ Power density in $\mathrm{W} / \mathrm{m}^{2}$

$E_{D}$ Wind energy density $\mathrm{W} / \mathrm{m}^{2}$

$E_{S} \quad$ Total energy available in the wind spectra during the period, $\mathrm{kWh} / \mathrm{m}^{2}$ 
$E_{A G} \quad$ Energy available for the wind turbine, $\mathrm{kWh} / \mathrm{m}^{2}$

$v_{m}$ Mean wind velocity

$v_{F \max } \quad$ Most frequent wind speed

$v_{E \max } \quad$ Velocity containing maximum energy in a wind regime

\section{Contribution/ Originality}

This study is one of very few studies which have investigated the wind energy potential of Cameroon in an exhaustive manner covering all the regions. It also proposes the prospect of harnessing the energy of the wind and recommends the Savonius rotor as the wind turbine generator of choice in Cameroon.

\section{INTRODUCTION}

Following the growth and employment strategic paper which is the reference framework for Cameroon government's action up to the year 2035, part of the long term vision of Cameroon is to be an emerging economy with an improved access to the development of energy infrastructure. For this to be possible the same paper stipulates a doubling of the national power consumption by 2020. As of present the primary energy production of Cameroon is as follows [1]: oil constitutes $17.3 \%$, hydro $4.9 \%$, combustible renewable and waste constitutes $77.8 \%$. The main source of electricity generation is from hydro (96\%) and a very little fraction from oil (4\%). Hence for Cameroon to attain its millennium development goals as well as being an emerging economy by 2035 there is need to develop the other sources of renewable energy. In terms of renewable energy exploitation; Cameroon as of now relies mostly on its rich hydro power potential which is the second in Africa estimated at 294 TWh/year (after the Democratic Republic of Congo with about $774 \mathrm{TWh} /$ year) [2,3]. With a rapid declining of the national oil reserves, there is an active campaign by the government to promote the exploitation of alternative energy resources to boost up the energy situation. The general situation in the Cameroon's energy sector according to an IEA, World Bank, IRENA, and UN data is presented in table 1.

The solar energy potential of Cameroon is abundant especially in the dry season that ranges from October to march every year in a major part of the country. This resource estimated to range from about $4 \mathrm{kWh} / \mathrm{d} / \mathrm{m}^{2}$ in the South to about $5.8 \mathrm{kWh} / \mathrm{d} / \mathrm{m}^{2}$ in the North, however is presently insufficiently developed and poorly documented. 
Table-1. General situation in energy sector

\begin{tabular}{l|l|l}
\hline Indicator & $\mathbf{2 0 0 9}$ & $\mathbf{1 9 9 0}$ \\
\hline Total primary energy supply: & $80,5 \mathrm{TWh}$ & $57,9 \mathrm{TWh}$ \\
\hline Energy consumption per capita: & $\begin{array}{l}\mathrm{T}, 2 \\
\mathrm{MWh} / \text { capita }\end{array}$ & $\begin{array}{l}3,0 \\
\mathrm{MWh} / \text { capita }\end{array}$ \\
\hline Electricity consumption: & $5,20 \mathrm{TWh}$ & $2,35 \mathrm{TWh}$ \\
\hline Electricity consumption per capita: & $271 \mathrm{kWh} /$ capita & \\
\hline Access to electricity: & $49 \%$ & \\
\hline Access to electricity urban population & $88 \%$ & \\
\hline Access to electricity rural population & $\sim 14 \%$ & \\
\hline Energy imports (\% of energy use) & $-28 \%$ & $-120 \%$ \\
\hline Electricity imports (\% of electricity use) & $0 \%$ & \\
\hline Power production capacity: & $1115 \mathrm{MW}$ & $627 \mathrm{MW}$ \\
\hline Hydro power production capacity: & $805 \mathrm{MW}$ & $530 \mathrm{MW}$ \\
\hline Electricity production: & $5,61 \mathrm{TWh}$ & $2,70 \mathrm{TWh}$ \\
\hline Hydro electricity production: & $4,23 \mathrm{TWh}$ & $2,66 \mathrm{TWh}$ \\
\hline Fossil fuels $\%$ of total energy & $30,9 \%$ & $18,7 \%$ \\
\hline
\end{tabular}

Sources: (IEA, World Bank, IRENA, UN data)

Some attempts have been made in the past to study the wind energy potential of Cameroon but this was limited only the three northern regions of the country. The study was based on data published by the observation network of the National Meteorology Department, located in the Adamoua and Northern Cameroon regions [4].

Even though studies pointed out the feasibility of wind energy exploitation for applications such as irrigation electricity supply for small house holds it was pointed out that the study needed reinforcement by additional observations in more sites within the region of interest before general conclusions on wind energy exploitation could be made.

The starting point towards the implementation of a wind energy project in a region, is the thorough understanding of the prevalent characteristic wind regimes. Consequently there need to be a systematic analysis of the short term and long term wind velocity distribution from which the energy density of the site can be estimated. Such information is required for the choice and optimal sizing of the appropriate wind turbines for the region of interest.

In the present study, the energy potential for wind regimes of different regions of Cameroon will be analysed and based on the results, recommendations would be made for the harnessing and the exploitation of the available wind resource of the country. The methodology adopted in the analysis is that proposed in [5].

The data for this analysis is obtained from the RETScreen software tool provided by CANMET Canada for all the regions of Cameroon. The software, contains data for some 4,700 ground stations located around the globe and directly incorporating the improved NASA surface meteorology and solar energy dataset for populated areas.

\section{STATISTICAL DISTRIBUTION OF WIND SPEED}

The Weibull distribution has been thoroughly investigated and established as the main tool for wind data analysis [6-8]. It can be used in characterising wind regimes in terms of its 
probability density function $f(V)$ and cumulative distribution function $F(V)$. These two functions are given by:

$$
F(V)=1-\exp -\left(\frac{V}{c}\right)^{k}
$$

and

$$
f(V)=\frac{d F}{d V}=\frac{k}{c}\left(\frac{V}{c}\right)^{k-1} \exp -\left(\frac{V}{c}\right)^{k}
$$

In these two expressions, $\mathrm{k}$ and $\mathrm{c}$ which are known as the shape and scale factors are characteristic parameters of the specific wind regime or the site of measurement. These two parameters determine the wind speed for optimum performance of a wind energy conversion system as well as the speed range over which the device is likely to operate.

Their determination necessitates a generous measurement of field data especially spread over relatively shorter time intervals. A particular case of the Weibull distribution is the Rayleigh distribution for which the shape factor is 2 . The validity of the Rayleigh distribution for wind energy analysis has also been demonstrated in established [9] where several sites were considered for which with long term wind data was available. The American Wind Energy Association has also recommended the use of the Rayleigh distribution for it fits excellently with observed wind velocity and power histograms.

With $\mathrm{k}=2$, the two functions in equations (1) and (2) reduce to:

$$
F(V)=1-\exp -\left[\frac{\pi}{4}\left(\frac{V}{V_{m}}\right)^{2}\right]
$$

and

$$
f(V)=\frac{\pi}{2} \frac{V}{V_{m}^{2}} \exp -\left[\frac{\pi}{4}\left(\frac{V}{V_{m}}\right)^{2}\right]
$$

From these two equations emerge the relevance of the Rayleigh distribution over the Weibull distribution with its distinct ability to standardize a site from the knowledge only of the mean wind velocity.

\section{DETERMINATION OF WIND ENERGY DENSITY AND ENERGY AVAILABLE IN THE WIND SPECTRA}

The power density in a wind stream is given by

$$
P_{D}=\frac{1}{2} \rho V^{3}
$$

Using this expression together with the Rayleigh probability distribution the wind energy density of a site is expressed as: 
$E_{D}=\int_{0}^{\infty} P_{D} f(V) d V$

If we adopt $\alpha=\frac{\pi}{4 V_{m}{ }^{2}}$, then we can deduce from equations (4) to (6) that:

$$
E_{D}=\alpha \rho \int_{0}^{\infty} V^{4} \exp \left(-\alpha V^{2}\right) d V
$$

The evaluation of this integral by applying the gamma function yields:

$$
E_{D}=\frac{3 \rho \sqrt{\pi}}{8 \alpha^{3 / 2}}
$$

The energy density can then be used to estimate a value of the energy available in the wind spectra $\left(E_{S}\right)$ for some determined time interval T. Hence;

$$
E_{S}=\frac{3 \rho \sqrt{\pi}}{8 \alpha^{3 / 2}} T
$$

From the probability density function we would notice that the most frequent wind speed is given by:

$$
V_{F \max }=\frac{1}{\sqrt{2 \alpha}}
$$

Now in reality, it is not the most frequent wind speed that is more energetic but a higher wind speed. Wind turbines are generally designed to operate at their maximum efficiency point corresponding to a wind velocity usually called the design wind speed $\left(V_{D}\right)$; which is higher than the most frequent wind speed [5]. The design wind speed $\left(V_{D}\right)$ most at times is chosen to correspond to the wind speed carrying the maximum amount of energy. Hence the designer would a priori like to identify $V_{D}$ for a particular site in order to produce wind turbines that would function optimally at the site.

The wind energy associated to any particular wind speed is given by:

$$
E_{V}=P_{D} f(V)
$$

Hence from equations (3) and (5), we get:

$$
E_{V}=\alpha \rho V^{4} \exp \left(-\alpha V^{2}\right)
$$

From equation (12) $E_{V}$ would be maximum at a wind velocity given by: 
$V_{E \max }=\sqrt{\frac{2}{\alpha}}$

If we reason in terms of the range of wind speeds at which a wind turbine functions; it will vary betrween the cut in wind speed $V_{\text {in }}$, the rated speed $V_{R}$ and the cut out wind speed $V_{\text {out }}$.

The wind turbine only starts rotating for wind speeds greater than $V_{\text {in }}$, attains maximum efficiency at $V_{R}$ while between $V_{R}$ and $V_{\text {out }}$ it is producing constant power corresponding to the rated velocity of the wind turbine. Above the cut out wind velocity $V_{\text {out }}$ the wind turbine is shut down to avoid being destroyed by the strong wind which at this time would be producing a very high thrust force.

Hence the effective power that can be captured by the wind turbine is given by:

$$
\begin{aligned}
& E_{\text {eff }}=T \int_{V_{\text {in }}}^{V_{R}} P_{D}(V) f(V) d V+T P_{R} \int_{V_{R}}^{V_{\text {out }}} f(V) d V \\
& E_{\text {eff }}=T \alpha \rho \int_{V_{\text {in }}}^{V_{\text {out }}} V^{4} \exp \left(-\alpha V^{2}\right) d V+T P_{R} \int_{V_{R}}^{V_{\text {out }}} f(V) d V
\end{aligned}
$$

Which upon integrating and making use of the fact that $\int f(V) d V=F(V)$ leads to:

$$
E_{\text {eff }}=T \alpha \rho \int_{V_{\text {in }}}^{V_{R}} V^{4} \exp \left(-\alpha V^{2}\right) d V+\frac{1}{2} \rho V_{R}^{3} T\left[\exp \left(-\alpha V_{R}^{2}\right)-\exp \left(-\alpha V_{\text {out }}^{2}\right)\right]
$$

\section{WIND ENERGY POTENTIAL OF THE REGIONS OF CAMEROON}

The wind energy potential of some of the regions of Cameroon would be evaluated following the method analysed above. The details of the regions are presented in table 2 and Fig.1.

Fig-1. Map of Cameroon showing regions of study and mean monthly wind speeds (10m above ground) [10]

The towns chosen are representative of the different regions of Cameroon and the choice was also based on the availability of data. Fig.2 Shows the variation of the monthly mean wind speed all the year round of the representative towns. 
Table-2. Details of sites for which wind data is analysed

\begin{tabular}{l|l|l|l|l|l|l}
\hline No. & Region & $\begin{array}{l}\text { Representativ } \\
\text { e town }\end{array}$ & $\begin{array}{l}\text { Latitude }\left({ }^{\circ} \mathbf{E}\right. \\
)\end{array}$ & $\begin{array}{l}\text { Longitud } \\
\mathbf{e}\left({ }^{\circ} \mathbf{N}\right)\end{array}$ & $\begin{array}{l}\text { Elevation } \\
(\mathbf{m})\end{array}$ & $\begin{array}{l}\text { Sensor } \\
\text { location(m) }\end{array}$ \\
\hline 1 & Adamawa & Ngoundere & $7.32^{\circ} \mathrm{N}$ & $13.58^{\circ} \mathrm{E}$ & 808 & 10 \\
\hline 2 & North & Garoua & $9.30^{\circ} \mathrm{N}$ & $13.39^{\circ} \mathrm{E}$ & 424 & 10 \\
\hline 3 & Far North & Maroua & $10.6^{\circ} \mathrm{N}$ & $14.30^{\circ} \mathrm{E}$ & 387 & 10 \\
\hline 4 & $\begin{array}{l}\text { North } \\
\text { West }\end{array}$ & Bamenda & $6^{\circ} \mathrm{N}$ & $10.2^{\circ} \mathrm{E}$ & 785 & 10 \\
\hline 5 & South & Ebolowa & $2.9^{\circ} \mathrm{N}$ & $11.1^{\circ} \mathrm{E}$ & 503 & 10 \\
\hline 6 & Littoral & Douala & $4.06^{\circ} \mathrm{N}$ & $9.7^{\circ} \mathrm{E}$ & 390 & 10 \\
\hline 7 & $\begin{array}{l}\text { South } \\
\text { West }\end{array}$ & Fontem & $5.47^{\circ} \mathrm{N}$ & $9.88^{\circ} \mathrm{E}$ & 616 & 10 \\
\hline 8 & West & Bafoussam & $5.5^{\circ} \mathrm{N}$ & $10.5^{\circ} \mathrm{E}$ & 616 & 10 \\
\hline 9 & Centre & Yaounde & $3.87^{\circ} \mathrm{N}$ & $11.52^{\circ} \mathrm{E}$ & 539 & 10 \\
\hline 10 & East & Bertoua & $4.6^{\circ} \mathrm{N}$ & $13.7^{\circ} \mathrm{E}$ & 692 & 10 \\
\hline & & & & & \\
\hline
\end{tabular}

Fig-2. Annual mean wind speed of the different locations

We notice that the three most northern regions represented by the towns of Maroua, Garoua and Ngaoundere; have the best wind speeds ranging between 3 and $5 \mathrm{~m} / \mathrm{s}$. The rest of the towns have mean wind speeds ranging between 1.2 and $2.4 \mathrm{~m} / \mathrm{s}$. For conventional horizontal axis wind turbines the cut-in wind speed is about $4 \mathrm{~m} / \mathrm{s}$ which qualifies only the three northern regions for wind turbine applications. On the other hand, the savonius rotor which is a vertical axis wind turbine has a cut-in speed as low as $1 \mathrm{~m} / \mathrm{s}$ [11]. Hence there is some prospect for wind energy exploitation based on installation of the vertical axis savonius type wind turbine. Eventhough the wind velocities for some of the regions are low it is worth noting the persistence of such winds. Figs. 3 to 13 show the probability desity functions as well as the cumulative frequencies of the wind speeds based on the Rayleigh distribution. The fraction of time in a year for which the wind speed is greater that $1 \mathrm{~m} / \mathrm{s}$ is deduced from the cumulative frequencies and presented in Table 13. We note that Ebolowa has the lowest frequency of $66 \%$ followed by Yaounde with $75 \%$ while for the rest of the locations it is greater than $80 \%$. The energy available for an aero-enerator; $\mathrm{E}_{\mathrm{AG}}$ $\left(\mathrm{kW}-\mathrm{hr} / \mathrm{m}^{2} / \mathrm{month}\right)$ presented in tables 3 to 13 is based on this cut-in speed of $1 \mathrm{~m} / \mathrm{s}$ and the cutout is taken to be $12 \mathrm{~m} / \mathrm{s}$.

Fig-3. Rayleigh distribution of wind velocity at Ngaoundere.

Fig-4. Rayleigh distribution of wind velocity at Garoua.

Fig-5. Rayleigh distribution of wind velocity at Maroua.

Fig-6. Rayleigh distribution of wind velocity at Bamenda and Bafoussam.

Fig-7. Rayleigh distribution of wind velocity at Douala and Fontem.

Fig-8. Rayleigh distribution of wind velocity at Ebolowa.

Fig-9. Rayleigh distribution of wind velocity at Yaounde.

\section{RESULTS AND DISCUSSIONS}

The starting point towards the implementation of a wind energy project in a region, is the thorough understanding of the prevalent characteristic wind regimes. We have plotted in fig. 2 the 
annual mean wind speeds of all representative regions of Cameroon. From the wind speeds distribution, we see that there is some prospect for wind energy exploitation given that the mean wind speed $V_{m}$ is always greater that $1 \mathrm{~m} / \mathrm{s}$ which is the cut-in wind speed of the savonius rotor.

The analyses presented in sections 2 and 3 above was applied to the mean wind speed of different regions of cameroon, obtained from the NASA Langley Research Centre Atmospheric Science, based on the Rayleigh distribution. A number of wind energy parameters such as: most frequent wind speed $\left(V_{F \max }\right)$; the velocity containing maximum energy in a wind regime $\left(V_{E \max }\right.$ ); wind energy density $\left(E_{D}\right)$; total energy available in the wind spectra during the period $\left(E_{S}\right)$; and the energy available for the wind turbine during the period, $\left(E_{A G}\right)$; are tabulated in tables 3 to 12 .

Table-3. wind energy potential of Ngaoundere

\begin{tabular}{|c|c|c|c|c|c|c|}
\hline Month & $\begin{array}{l}V_{m} \\
(m / s)\end{array}$ & $\begin{array}{l}\mathbf{E}_{\mathrm{D}} \\
\left(\mathbf{W} / \mathbf{m}^{2}\right)\end{array}$ & $\begin{array}{l}\text { Es (kW- } \\
\text { hr/m2/ } \\
\text { month })\end{array}$ & $\begin{array}{l}V_{F} \\
(m / s)\end{array}$ & $\begin{array}{l}V_{E} \quad \operatorname{Max} \\
(m / s)\end{array}$ & $\begin{array}{l}\mathrm{E}_{\mathrm{AG}}(\mathrm{kW}- \\
\mathrm{hr} / \mathrm{m} 2 / \\
\text { month })\end{array}$ \\
\hline January & 3.4 & 45.79 & 32.97 & 2.71 & 5.43 & 24.8 \\
\hline February & 3.4 & 45.79 & 32.97 & 2.71 & 5.43 & 24.8 \\
\hline March & 3.7 & 59.01 & 42.49 & 2.95 & 5.9 & 27.83 \\
\hline April & 3.9 & 63.93 & 46.03 & 3.03 & 6.06 & 28.67 \\
\hline May & 3.6 & 54.35 & 39.14 & 2.87 & 5.74 & 26.91 \\
\hline June & 3.1 & 34.71 & 24.99 & 2.47 & 4.95 & 21.08 \\
\hline July & 2.9 & 28.41 & 20.46 & 2.31 & 4.63 & 18.33 \\
\hline August & 2.8 & 25.57 & 18.41 & 2.23 & 4.47 & 16.91 \\
\hline September & 2.6 & 20.48 & 14.74 & 2.07 & 4.15 & 14.07 \\
\hline October & 2.8 & 25.57 & 18.41 & 2.23 & 4.47 & 16.91 \\
\hline November & 3.2 & 34.71 & 24.99 & 2.47 & 4.95 & 21.08 \\
\hline December & 3.5 & 49.95 & 35.96 & 2.79 & 5.59 & 25.9 \\
\hline Annual & 3.3 & 38.18 & 27.49 & 2.55 & 5.11 & 22.39 \\
\hline
\end{tabular}

Table-4. wind energy potential of Garoua

\begin{tabular}{|c|c|c|c|c|c|c|}
\hline Month & $\mathbf{V}_{\mathrm{m}}(\mathrm{m} / \mathrm{s})$ & $\begin{array}{l}\mathbf{E}_{\mathrm{D}} \\
\left(\mathbf{W} / \mathbf{m}^{2}\right)\end{array}$ & $\begin{array}{l}\text { Es (kW- } \\
\text { hr/m2/ } \\
\text { month })\end{array}$ & $\begin{array}{l}\mathbf{V}_{\mathrm{F}} \\
(\mathrm{m} / \mathrm{s})\end{array}$ & $\begin{array}{l}V_{E} \\
(\mathrm{~m} / \mathrm{s})\end{array}$ & $\begin{array}{l}\mathrm{E}_{\mathrm{AG}} \quad(\mathrm{kW}- \\
\mathrm{hr} / \mathrm{m} 2 / \\
\text { month) }\end{array}$ \\
\hline January & 3.8 & 63.93 & 46.03 & 3.03 & 6.06 & 28.67 \\
\hline February & 3.8 & 63.93 & 46.03 & 3.03 & 6.06 & 28.67 \\
\hline March & 4.1 & 80.29 & 57.81 & 3.27 & 6.54 & 30.67 \\
\hline April & 4.3 & 92.63 & 66.69 & 3.43 & 6.86 & 31.59 \\
\hline May & 3.9 & 69.11 & 49.76 & 3.11 & 6.22 & 29.42 \\
\hline June & 3.3 & 41.87 & 30.14 & 2.63 & 5.27 & 23.63 \\
\hline July & 3 & 31.46 & 22.65 & 2.39 & 4.79 & 19.73 \\
\hline August & 2.9 & 28.41 & 20.46 & 2.31 & 4.63 & 18.33 \\
\hline September & 2.7 & 22.93 & 16.51 & 2.15 & 4.31 & 15.49 \\
\hline October & 3 & 31.46 & 22.65 & 2.39 & 4.79 & 19.73 \\
\hline November & 3.5 & 49.95 & 35.96 & 2.79 & 5.59 & 25.9 \\
\hline December & 4 & 74.56 & 53.68 & 3.19 & 6.38 & 30.09 \\
\hline Annual & 3.5 & 49.95 & 35.96 & 2.79 & 5.59 & 25.9 \\
\hline
\end{tabular}


Table-5. wind energy potential of Maroua

\begin{tabular}{|c|c|c|c|c|c|c|}
\hline Month & $\begin{array}{l}V_{m} \\
(m / s)\end{array}$ & $\begin{array}{l}\mathbf{E}_{\mathbf{D}} \\
\left(\mathbf{W} / \mathbf{m}^{2}\right)\end{array}$ & $\begin{array}{l}\text { Es (kW- } \\
\mathrm{hr} / \mathrm{m} 2 / \\
\text { month })\end{array}$ & $\begin{array}{l}V_{F} \\
(m / s)\end{array}$ & $\begin{array}{l}V_{E} \quad \text { Max } \\
(\mathrm{m} / \mathrm{s})\end{array}$ & $\begin{array}{l}\mathrm{E}_{\mathrm{AG}}(\mathrm{kW}- \\
\mathrm{hr} / \mathrm{m} 2 / \\
\text { month })\end{array}$ \\
\hline January & 4.3 & 92.63 & 66.69 & 3.43 & 6.86 & 31.59 \\
\hline February & 4.2 & 86.31 & 62.15 & 3.35 & 6.7 & 31.17 \\
\hline March & 4.6 & 113.4 & 81.65 & 3.67 & 7.34 & 32.43 \\
\hline April & 4.7 & 120.96 & 87.09 & 3.75 & 7.5 & 32.59 \\
\hline May & 4.3 & 92.63 & 66.69 & 3.43 & 6.86 & 31.59 \\
\hline June & 3.6 & 54.35 & 39.14 & 2.87 & 5.74 & 26.91 \\
\hline July & 3.3 & 41.87 & 30.14 & 2.63 & 5.27 & 23.63 \\
\hline August & 3.2 & 38.18 & 27.49 & 2.55 & 5.11 & 22.39 \\
\hline September & 2.9 & 28.41 & 20.46 & 2.31 & 4.63 & 18.33 \\
\hline October & 3.3 & 41.87 & 30.14 & 2.63 & 5.27 & 23.63 \\
\hline November & 3.9 & 69.11 & 49.76 & 3.11 & 6.22 & 29.42 \\
\hline December & 4.5 & 106.16 & 76.44 & 3.59 & 7.18 & 32.22 \\
\hline Annual & 3.9 & 69.11 & 49.76 & 3.11 & 6.22 & 29.42 \\
\hline
\end{tabular}

Table-6. wind energy potential of Bamenda

\begin{tabular}{|c|c|c|c|c|c|c|}
\hline Month & $\mathbf{V}_{\mathrm{m}}(\mathbf{m} / \mathbf{s})$ & $\begin{array}{l}\mathbf{E}_{\mathrm{D}} \\
\left(\mathbf{W} / \mathbf{m}^{2}\right)\end{array}$ & $\begin{array}{l}\text { Es } \quad(\mathrm{kW}- \\
\mathrm{hr} / \mathrm{m} 2 / \\
\text { month })\end{array}$ & $\begin{array}{l}\mathbf{V}_{\mathrm{F}} \\
(\mathrm{m} / \mathrm{s})\end{array}$ & $\begin{array}{l}V_{\mathrm{E}} \\
(\mathrm{m} / \mathrm{s})\end{array}$ & $\begin{array}{l}\mathrm{E}_{\mathrm{AG}} \quad(\mathrm{kW}- \\
\mathrm{hr} / \mathrm{m} 2 / \\
\text { month) }\end{array}$ \\
\hline January & 2.1 & 10.79 & 7.77 & 1.68 & 3.35 & 7.71 \\
\hline February & 2.2 & 12.41 & 8.93 & 1.76 & 3.51 & 8.84 \\
\hline March & 2.1 & 10.79 & 7.77 & 1.68 & 3.35 & 7.71 \\
\hline April & 1.9 & 7.99 & 5.75 & 1.52 & 3.03 & 5.72 \\
\hline May & 1.8 & 6.79 & 4.89 & 1.44 & 2.87 & 4.85 \\
\hline June & 2 & 9.32 & 6.71 & 1.6 & 3.19 & 6.67 \\
\hline July & 1.9 & 7.99 & 5.75 & 1.52 & 3.03 & 5.72 \\
\hline August & 2 & 9.32 & 6.71 & 1.6 & 3.19 & 6.67 \\
\hline September & 1.8 & 6.79 & 4.89 & 1.44 & 2.87 & 4.85 \\
\hline October & 1.6 & 4.77 & 3.44 & 1.28 & 2.55 & 3.39 \\
\hline November & 1.7 & 5.72 & 4.12 & 1.36 & 2.71 & 4.08 \\
\hline December & 1.8 & 6.79 & 4.89 & 1.44 & 2.87 & 4.85 \\
\hline Annual & 1.9 & 7.99 & 5.75 & 1.52 & 3.03 & 5.72 \\
\hline
\end{tabular}

Table-7. wind energy potential of Ebolowa

\begin{tabular}{|c|c|c|c|c|c|c|}
\hline Month & $\begin{array}{l}V_{\mathrm{m}} \\
(\mathrm{m} / \mathrm{s})\end{array}$ & $\begin{array}{l}\mathbf{E}_{\mathbf{D}} \\
\left(\mathbf{W} / \mathbf{m}^{2}\right)\end{array}$ & $\begin{array}{l}\text { Es (kW- } \\
\mathrm{hr} / \mathrm{m} 2 / \\
\text { month })\end{array}$ & $\begin{array}{l}V_{F} \\
(\mathrm{~m} / \mathrm{s})\end{array}$ & $\begin{array}{l}V_{E} \quad \text { Max } \\
(\mathrm{m} / \mathrm{s})\end{array}$ & $\begin{array}{l}\mathrm{E}_{\mathrm{AG}}(\mathrm{kW}- \\
\mathrm{hr} / \mathrm{m} \mathrm{g} / \\
\text { month })\end{array}$ \\
\hline January & 1.6 & 4.77 & 3.44 & 1.28 & 2.55 & 3.39 \\
\hline February & 1.8 & 6.79 & 4.89 & 1.44 & 2.87 & 4.85 \\
\hline March & 1.5 & 3.93 & 2.83 & 1.2 & 2.39 & 2.78 \\
\hline April & 1.2 & 2.01 & 1.45 & 0.96 & 1.91 & 1.38 \\
\hline May & 1.2 & 2.01 & 1.45 & 0.96 & 1.91 & 1.38 \\
\hline June & 1.3 & 2.56 & 1.84 & 1.04 & 2.07 & 1.78 \\
\hline July & 1.5 & 3.93 & 2.83 & 1.2 & 2.39 & 2.78 \\
\hline August & 1.7 & 5.72 & 4.12 & 1.36 & 2.71 & 4.08 \\
\hline September & 1.6 & 4.77 & 3.44 & 1.28 & 2.55 & 3.39 \\
\hline October & 1.3 & 2.56 & 1.84 & 1.04 & 2.07 & 1.78 \\
\hline November & 1.2 & 2.01 & 1.45 & 0.96 & 1.91 & 1.38 \\
\hline December & 1.3 & 2.56 & 1.84 & 1.04 & 2.07 & 1.78 \\
\hline Annual & 1.4 & 3.2 & 2.3 & 1.12 & 2.23 & 2.25 \\
\hline
\end{tabular}


Table-8. wind energy potential of Douala

\begin{tabular}{|c|c|c|c|c|c|c|}
\hline Month & $\mathbf{V}_{\mathrm{m}}(\mathrm{m} / \mathrm{s})$ & $\begin{array}{l}\mathbf{E}_{\mathbf{b}} \\
\left(\mathbf{W} / \mathbf{m}^{2}\right)\end{array}$ & $\begin{array}{l}\text { Es (kW- } \\
\text { hr/m2/ } \\
\text { month) }\end{array}$ & $\begin{array}{l}\mathbf{V}_{\mathrm{F}} \\
(\mathrm{m} / \mathrm{s})\end{array}$ & $\begin{array}{l}V_{E} \\
(m / s)\end{array}$ & $\begin{array}{l}\mathrm{E}_{\mathrm{AG}}(\mathrm{kW}- \\
\mathrm{hr} / \mathrm{m} 2 / \\
\text { month) }\end{array}$ \\
\hline January & 1.9 & 7.99 & 5.75 & 1.52 & 3.03 & 5.72 \\
\hline February & 2 & 9.32 & 6.71 & 1.6 & 3.19 & 6.67 \\
\hline March & 1.8 & 6.79 & 4.89 & 1.44 & 2.87 & 4.85 \\
\hline April & 1.5 & 3.93 & 2.83 & 1.2 & 2.39 & 2.78 \\
\hline May & 1.5 & 3.93 & 2.83 & 1.2 & 2.39 & 2.78 \\
\hline June & 1.8 & 6.79 & 4.89 & 1.44 & 2.87 & 4.85 \\
\hline July & 2.1 & 10.79 & 7.77 & 1.68 & 3.35 & 7.71 \\
\hline August & 2.2 & 12.41 & 8.93 & 1.76 & 3.51 & 8.84 \\
\hline September & 2 & 9.32 & 6.71 & 1.6 & 3.19 & 6.67 \\
\hline October & 1.6 & 4.77 & 3.44 & 1.28 & 2.55 & 3.39 \\
\hline November & 1.4 & 3.2 & 2.3 & 1.12 & 2.23 & 2.25 \\
\hline December & 1.6 & 4.77 & 3.44 & 1.28 & 2.55 & 3.39 \\
\hline Annual & 1.8 & 6.79 & 4.89 & 1.44 & 2.87 & 4.85 \\
\hline
\end{tabular}

Table-9. wind energy potential of Fontem

\begin{tabular}{|c|c|c|c|c|c|c|}
\hline Month & $\begin{array}{l}\mathbf{V}_{\mathrm{m}} \\
(\mathrm{m} / \mathrm{s})\end{array}$ & $\begin{array}{l}\mathbf{E}_{\mathrm{D}} \\
\left(\mathbf{W} / \mathbf{m}^{2}\right)\end{array}$ & $\begin{array}{l}\text { Es (kW- } \\
\text { hr/m2/ } \\
\text { month })\end{array}$ & $\begin{array}{l}V_{F} \\
(m / s)\end{array}$ & $\begin{array}{l}V_{E} \quad \operatorname{Max} \\
(\mathrm{m} / \mathrm{s})\end{array}$ & $\begin{array}{l}\mathrm{E}_{\mathrm{AG}} \quad(\mathrm{kW}- \\
\mathrm{hr} / \mathrm{m} 2 / \\
\text { month })\end{array}$ \\
\hline January & 2 & 9.32 & 6.71 & 1.6 & 3.19 & 6.67 \\
\hline February & 2.1 & 10.79 & 7.77 & 1.68 & 3.35 & 7.71 \\
\hline March & 1.9 & 7.99 & 5.75 & 1.52 & 3.03 & 5.72 \\
\hline April & 1.6 & 4.77 & 3.44 & 1.28 & 2.55 & 3.39 \\
\hline May & 1.6 & 4.77 & 3.44 & 1.28 & 2.55 & 3.39 \\
\hline June & 1.9 & 7.99 & 5.75 & 1.52 & 3.03 & 5.72 \\
\hline July & 1.9 & 7.99 & 5.75 & 1.52 & 3.03 & 5.72 \\
\hline August & 2 & 9.32 & 6.71 & 1.6 & 3.19 & 6.67 \\
\hline September & 1.8 & 6.79 & 4.89 & 1.44 & 2.87 & 4.85 \\
\hline October & 1.5 & 3.93 & 2.83 & 1.2 & 2.39 & 2.78 \\
\hline November & 1.6 & 4.77 & 3.44 & 1.28 & 2.55 & 3.39 \\
\hline December & 1.6 & 4.77 & 3.44 & 1.28 & 2.55 & 3.39 \\
\hline Annual & 1.8 & 6.79 & 4.89 & 1.44 & 2.87 & 4.85 \\
\hline
\end{tabular}

Table-10. wind energy potential of Bafoussam

\begin{tabular}{|c|c|c|c|c|c|c|}
\hline Month & $\mathrm{V}_{\mathrm{m}}(\mathrm{m} / \mathrm{s})$ & $\begin{array}{l}\mathbf{E}_{\mathbf{D}} \\
\left(\mathbf{W} / \mathbf{m}^{2}\right)\end{array}$ & $\begin{array}{l}\text { Es (kW- } \\
\text { hr/m2/ } \\
\text { month) }\end{array}$ & $\begin{array}{l}V_{\mathrm{F}} \\
(\mathrm{m} / \mathrm{s})\end{array}$ & $\begin{array}{l}V_{E} \\
(m / s)\end{array}$ & $\begin{array}{l}\mathrm{E}_{\mathrm{AG}}(\mathrm{kW}- \\
\mathrm{hr} / \mathrm{me} / \\
\text { month) }\end{array}$ \\
\hline January & 2.1 & 10.79 & 7.77 & 1.68 & 3.35 & 7.71 \\
\hline February & 2.2 & 12.41 & 8.93 & 1.76 & 3.51 & 8.84 \\
\hline March & 2.1 & 10.79 & 7.77 & 1.68 & 3.35 & 7.71 \\
\hline April & 1.9 & 7.99 & 5.75 & 1.52 & 3.03 & 5.72 \\
\hline May & 1.8 & 6.79 & 4.89 & 1.44 & 2.87 & 4.85 \\
\hline June & 2 & 9.32 & 6.71 & 1.6 & 3.19 & 6.67 \\
\hline July & 1.9 & 7.99 & 5.75 & 1.52 & 3.03 & 5.72 \\
\hline August & 2 & 9.32 & 6.71 & 1.6 & 3.19 & 6.67 \\
\hline September & 1.8 & 6.79 & 4.89 & 1.44 & 2.87 & 4.85 \\
\hline October & 1.6 & 4.77 & 3.44 & 1.28 & 2.55 & 3.39 \\
\hline November & 1.7 & 5.72 & 4.12 & 1.36 & 2.71 & 4.08 \\
\hline December & 1.8 & 6.79 & 4.89 & 1.44 & 2.87 & 4.85 \\
\hline Annual & 1.9 & 7.99 & 5.75 & 1.52 & 3.03 & 5.72 \\
\hline
\end{tabular}


Table-1 1. wind energy potential of Yaounde

\begin{tabular}{|c|c|c|c|c|c|c|}
\hline Month & $\begin{array}{l}\mathrm{V}_{\mathrm{m}} \\
(\mathrm{m} / \mathrm{s})\end{array}$ & $\begin{array}{l}\mathbf{E}_{\mathrm{D}} \\
\left(\mathbf{W} / \mathbf{m}^{2}\right)\end{array}$ & $\begin{array}{l}\text { Es (kW- } \\
\text { hr/me/ } \\
\text { month) }\end{array}$ & $\begin{array}{l}V_{F} \quad \text { Max } \\
(\mathrm{m} / \mathrm{s})\end{array}$ & $\begin{array}{l}V_{E} \quad \text { Max } \\
(m / s)\end{array}$ & $\begin{array}{l}\mathrm{E}_{\mathrm{AG}}(\mathrm{kW}- \\
\mathrm{hr} / \mathrm{m} \mathrm{g} / \\
\text { month })\end{array}$ \\
\hline January & 1.7 & 5.72 & 4.12 & 1.36 & 2.71 & 4.08 \\
\hline February & 1.9 & 7.99 & 5.75 & 1.52 & 3.03 & 5.72 \\
\hline March & 1.6 & 4.77 & 3.44 & 1.28 & 2.55 & 3.39 \\
\hline April & 1.3 & 2.56 & 1.84 & 1.04 & 2.07 & 1.78 \\
\hline May & 1.2 & 2.01 & 1.45 & 0.96 & 1.91 & 1.38 \\
\hline June & 1.4 & 3.2 & 2.3 & 1.12 & 2.23 & 2.25 \\
\hline July & 1.5 & 3.93 & 2.83 & 1.2 & 2.39 & 2.78 \\
\hline August & 1.7 & 5.72 & 4.12 & 1.36 & 2.71 & 4.08 \\
\hline September & 1.6 & 4.77 & 3.44 & 1.28 & 2.55 & 3.39 \\
\hline October & 1.3 & 2.56 & 1.84 & 1.04 & 2.07 & 1.78 \\
\hline November & 1.2 & 2.01 & 1.45 & 0.96 & 1.91 & 1.38 \\
\hline December & 1.3 & 2.56 & 1.84 & 1.04 & 2.07 & 1.78 \\
\hline Annual & 1.5 & 3.93 & 2.83 & 1.2 & 2.39 & 2.78 \\
\hline
\end{tabular}

Table-12. wind energy potential of Bertoua

\begin{tabular}{|c|c|c|c|c|c|c|}
\hline Month & $\begin{array}{l}\mathrm{V}_{\mathrm{m}} \\
(\mathrm{m} / \mathrm{s})\end{array}$ & $\begin{array}{l}\mathbf{E}_{\mathrm{D}} \\
\left(\mathbf{W} / \mathbf{m}^{2}\right)\end{array}$ & $\begin{array}{l}\text { Es (kW- } \\
\text { hr/me/ } \\
\text { month) }\end{array}$ & $\begin{array}{l}V_{F} \quad \text { Max } \\
(\mathrm{m} / \mathrm{s})^{\text {M }}\end{array}$ & $\begin{array}{l}V_{E} \quad \text { Max } \\
(m / s)\end{array}$ & $\begin{array}{l}\mathrm{E}_{\mathrm{AG}}(\mathrm{kW}- \\
\mathrm{hr} / \mathrm{m} 2 / \\
\text { month })\end{array}$ \\
\hline January & 2.2 & 12.41 & 8.93 & 1.76 & 3.51 & 8.84 \\
\hline February & 2.4 & 16.11 & 11.6 & 1.91 & 3.83 & 11.34 \\
\hline March & 2.2 & 12.41 & 8.93 & 1.76 & 3.51 & 8.84 \\
\hline April & 2.1 & 10.79 & 7.77 & 1.68 & 3.35 & 7.71 \\
\hline May & 1.9 & 7.99 & 5.75 & 1.52 & 3.03 & 5.72 \\
\hline June & 1.8 & 6.79 & 4.89 & 1.44 & 2.87 & 4.85 \\
\hline July & 1.8 & 6.79 & 4.89 & 1.44 & 2.87 & 4.85 \\
\hline August & 1.8 & 6.79 & 4.89 & 1.44 & 2.87 & 4.85 \\
\hline September & 1.8 & 6.79 & 4.89 & 1.44 & 2.87 & 4.85 \\
\hline October & 1.7 & 5.72 & 4.12 & 1.36 & 2.71 & 4.08 \\
\hline November & 1.7 & 5.72 & 4.12 & 1.36 & 2.71 & 4.08 \\
\hline December & 1.9 & 7.99 & 5.75 & 1.52 & 3.03 & 5.72 \\
\hline Annual & 1.9 & 7.99 & 5.75 & 1.52 & 3.03 & 5.72 \\
\hline
\end{tabular}

Table-13. Percentage of time for which the wind speed is greater than $1 \mathrm{~m} / \mathrm{s}$ all year round

\begin{tabular}{|c|c|c|c|}
\hline No. & Region & Representative town & $\begin{array}{l}\% \text { of Time for which } V_{m}> \\
1 \mathrm{~m} / \mathrm{s}\end{array}$ \\
\hline 1 & Adamawa & Ngoundere & 96 \\
\hline 2 & North & Garoua & 96 \\
\hline 3 & Far North & Maroua & 97 \\
\hline 4 & North West & Bamenda & 80 \\
\hline 5 & South & Ebolowa & 66 \\
\hline 6 & Littoral & Douala & 80 \\
\hline 7 & South West & Fontem & 80 \\
\hline 8 & West & Bafoussam & 80 \\
\hline 9 & Centre & Yaounde & 75 \\
\hline 10 & East & Bertoua & 80 \\
\hline
\end{tabular}


The energy available for the wind turbine $\left(E_{A G}\right)$ is calculated based on a cut-in speed of $1 \mathrm{~m} / \mathrm{s}$ and a cut-out speed of $12 \mathrm{~m} / \mathrm{s}$ and plotted for the different regions in fig. 10.

Fig-10. Energy available in the wind spectra

We see in fig. 10 that the three northern regions are best for wind turbine installation as alreated stipulated in [4, 10]. In addition, all the other regions have an $E_{A G}$ ranging between 1.38 to 8.84 ( $\mathrm{kW}-\mathrm{hr} / \mathrm{m}^{2} /$ month). Hence wind energy can be exploited over the entire nation of Cameroon in two instances: for the three northern regions the energy can be exported to the national grid while for the seven southern regions installations can be made for stand-alone applications requiring less energy like lighting in rural households, irrigation, water pumping, battery charging etc.

The Rayleigh distribution adopted in this research uses the mean wind speed as the input parameter, consequently the results of this research can be applied in other regions of Cameroon and beyond with similar mean wind speeds, for the evaluation of the wind energy potential. In particular the methodology used gives allowance for the energy available in the wind spectra that can be practically captured by a given wind turbine, during a given period, $\left(E_{A G}\right)$ provided the designed cut-in and cut-out wind speeds are known. Consequently the results of this research can serve at least a dual purpose: they can be directly exploited on one hand by policy makers in Cameroon in view of giving orientation for the exploitation of wind energy, and on the other hand by wind turbine manufacturers in designing wind turbines that can operate in the range of the velocity containing maximum energy in the wind regimes $\left(V_{E \max }\right)$ characteristic of the regions of Cameroon. The research results can also be exploited by households especially in the rural areas to install stand-alone wind energy systems in an attempt to curb the present prevalent erratic energy supply.

\section{CONCLUSIONS}

The wind energy potential of all the regions of Cameroon is modelled using the Rayleigh probability distribution and using the methodology of Sathyajith, et al. [5]. Parameters characterising wind energy potential such as: most frequent wind speed $\left(V_{F \max }\right)$; the velocity containing maximum energy in a wind regime $\left(V_{E \max }\right)$; wind energy density $\left(E_{D}\right)$; total energy available in the wind spectra during a given period $\left(E_{S}\right)$; and the energy available for the wind 
turbine during during a given period, $\left(E_{A G}\right)$; are tabulated in tables for all the regions of Cameroon.

We have shown that the three most northern regions are very fruitful for conventional horizontal axis wind turbines installation that can be connected to the national grid. The wind resource of the other regions can be exploited using say a savonius wind turbine having a cut-in speed of $1 \mathrm{~m} / \mathrm{s}$ for low energy and stand-alone applications like lighting in rural households, irrigation, water pumping and battery charging.

\section{REFERENCES}

[1] Growth and Employment Strategy Paper 2010/2020, "August 2012. In: Cameroon: Poverty reduction strategy paper. IMF Country Report No. 10/257.

www.imf.org/external/pubs/ft/scr/2010/cr10257.pdf Policy DB Details: Cameroon (2012)," Renewable Energy E Energy Efficiency Partnership (REEEP). Available: http://www.reeep.org/index.php?id=9353\&text=\&special=viewitem\&cid=67, 2012.

[2] IEA Country Energy Balance, Available: http://www.laurea.fi/en/connect/results/Documents/Cameroon\%20Country\%20Report.pdf, 2009.

[3] N. Emmanuel and T. Elie, "Energy systems: Vulnerability - adaptation - resilience (VAR)," Regional Focus: Sub-Saharan Africa-Cameroon. Helio International Report. Available: www.heliointernational.org2009.

[4] R. Tchinda and E. Kaptouom, "Wind energy in adamaoua and North Cameroon provinces energy," Conversion and Management, vol. 44, pp. 845-857, 2003.

[5] M. Sathyajith, K. P. Pandey, and K. V. Anil, "Analysis of wind regimes for energy estimation," Renewable Energy, vol. 25, pp. 381-399, 2002.

[6] F. C. Odo, S. U. Offiah, and P. E. Ugwuoke, "Weibull distribution based model for prediction of wind potential in Enugu, Nigeria," Advances in Applied Science Research, vol. 3, pp. 1202-1208, 2012.

[7] L. Lu, H. Yang, and J. Burnett, "Investigation of wind power potential on Hong Kong Islands - an analysis of wind power and wind turbine characteristics," Renewable Energy, vol. 27, pp. 1-12, 2002.

[8] P. Bhattacharya, "A study on weibull distribution for estimating the parameters," Journal of Applied Quantitative Methods, vol. 5, pp. 234-241, 2010.

[9] R. B. Corotis, A. B. Sigl, and J. Klein, "Probability models for wind velocity magnitude and persistence," Solar Energy, vol. 20, pp. 483-493, 1978.

[10] N. B. Bobbo, "An assessment of cameroon's renewable energy resource potential and prospects for a sustainable economic development," Master Thesis, Brandenburg University of Technology Cottbus, Feb. $2011,2011$.

[11] D. L. Gourieres and Theorie, Conception et Calcul pratique des installations. Paris: Eyrolles, 1982. 


\section{Illustrations}

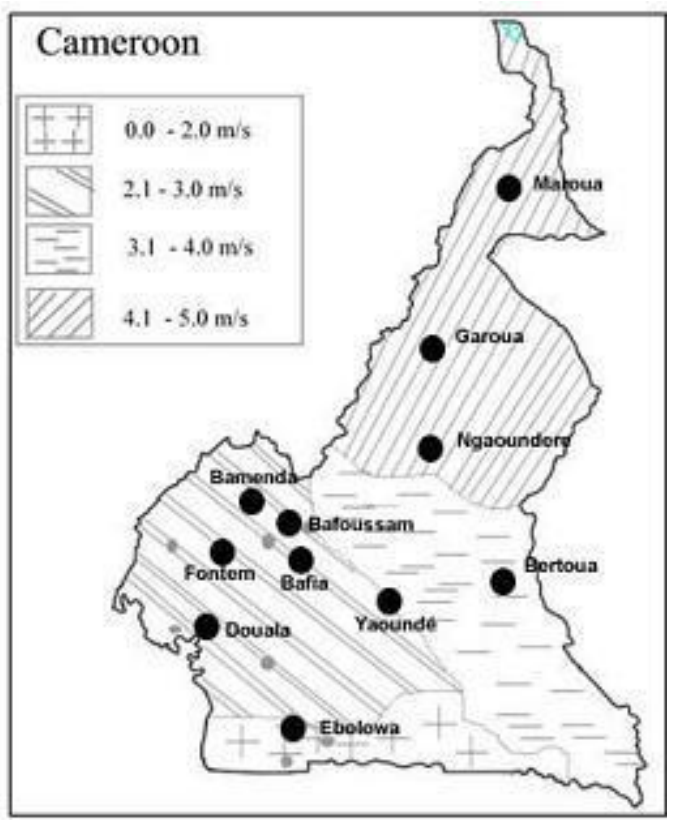

Fig-1. Map of Cameroon showing regions of study and mean monthly wind speeds (10m above ground) [11]

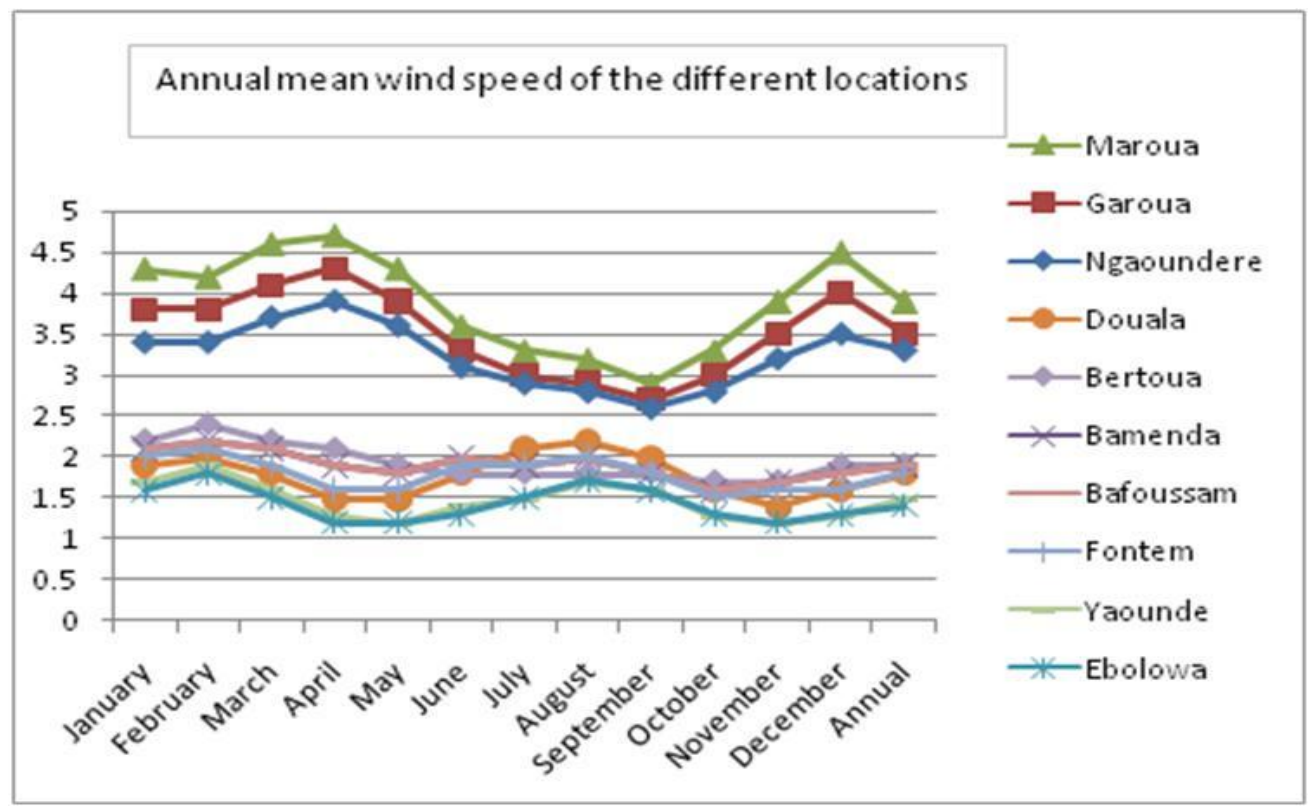

Fig-2. Annual mean wind speed of the different locations 


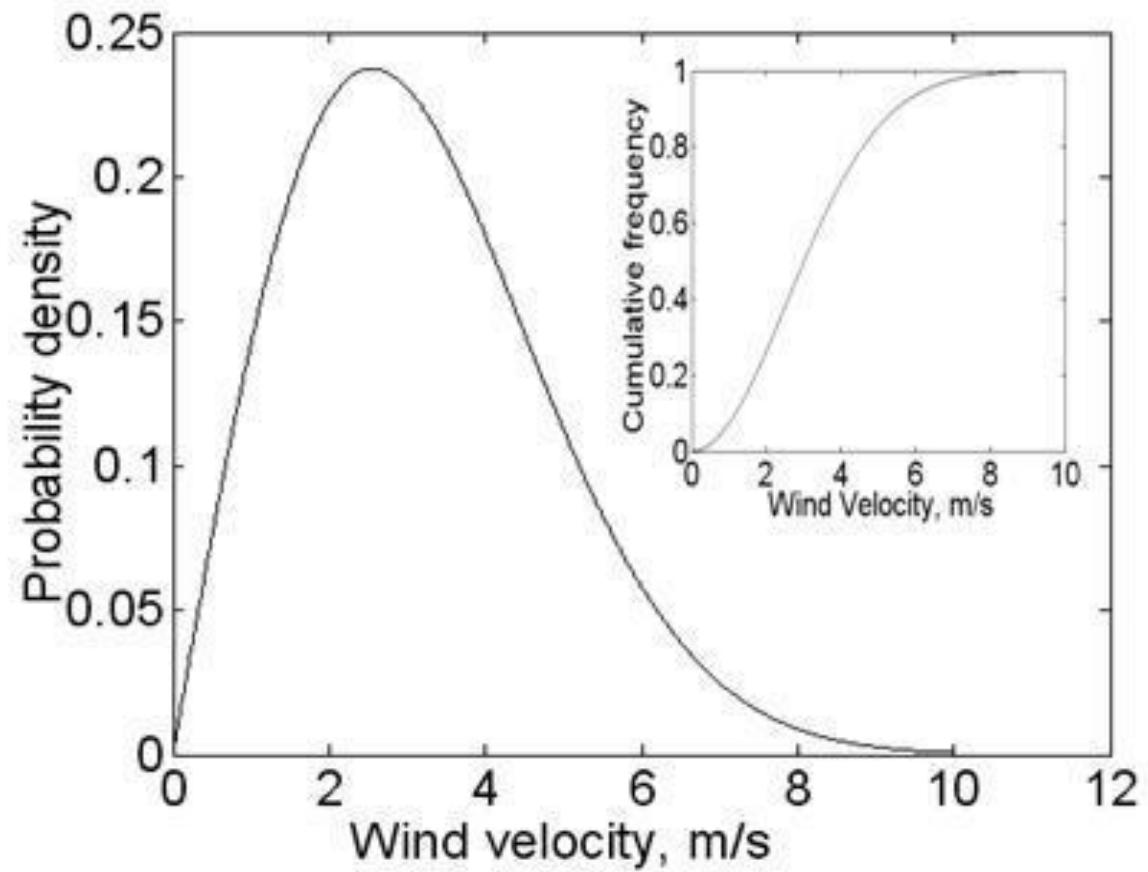

Fig-3. Rayleigh distribution of wind velocity at Ngaoundere.

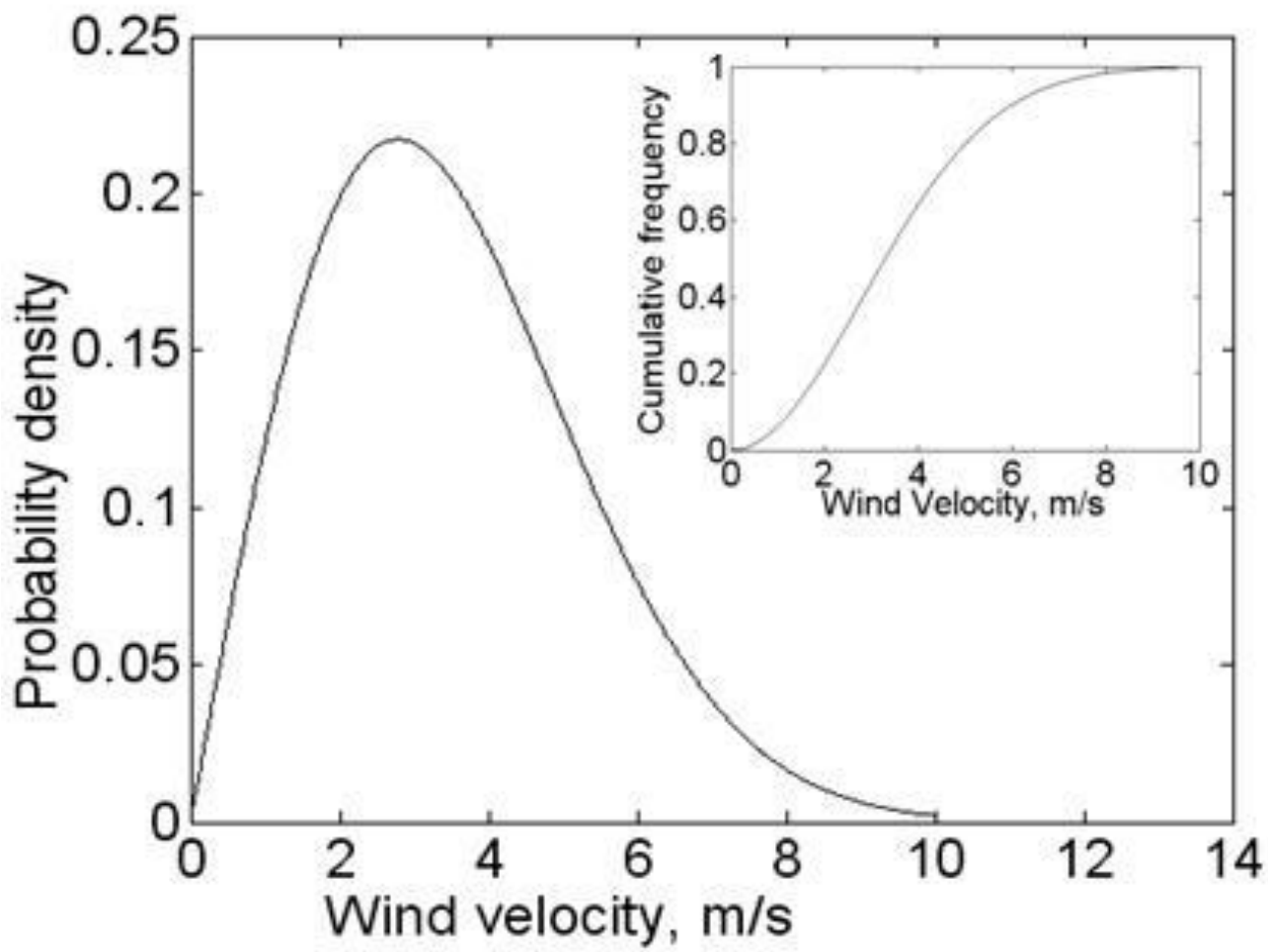

Fig-4. Rayleigh distribution of wind velocity at Garoua. 
Asian Journal of Energy Transformation and Conservation, 2014, 1(1): 26-43

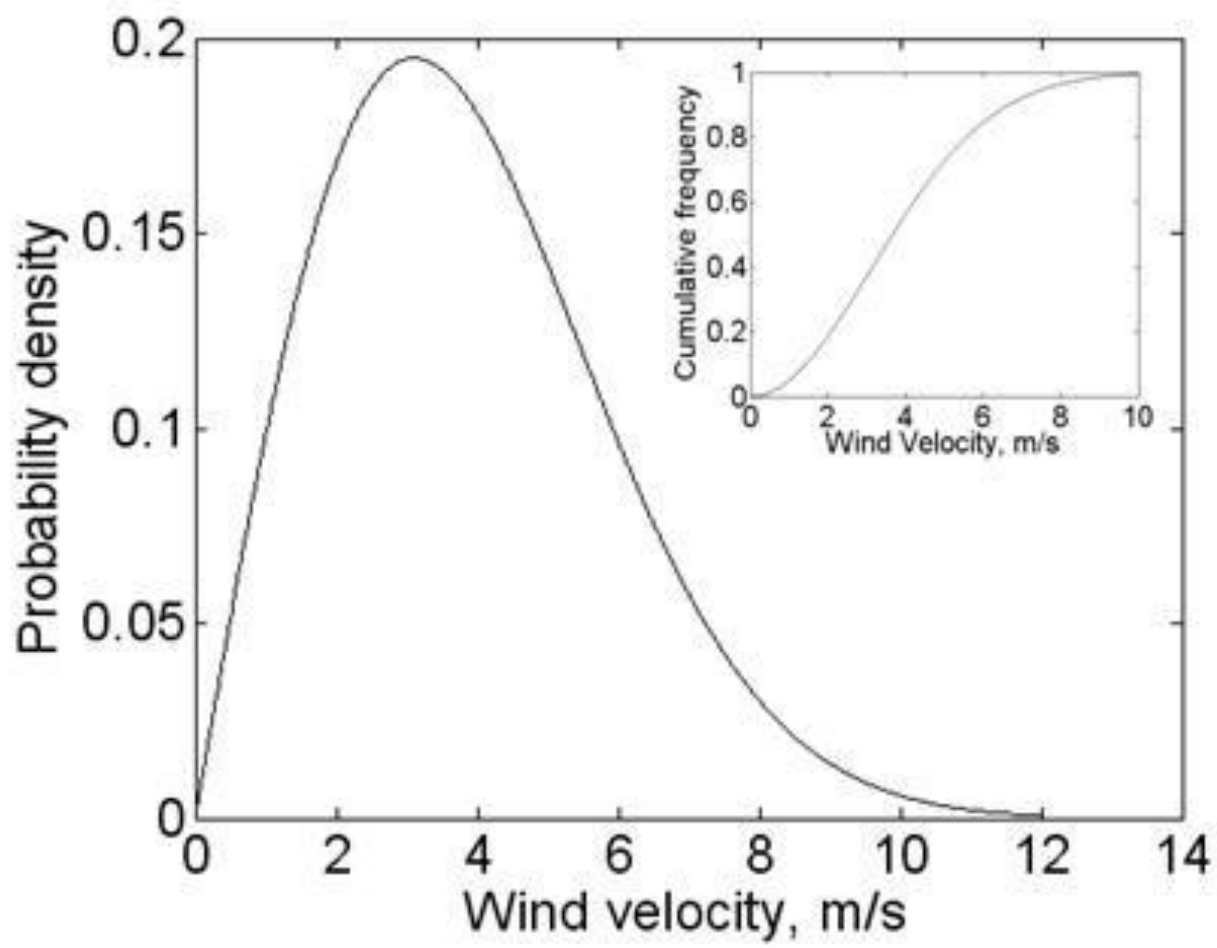

Fig-5. Rayleigh distribution of wind velocity at Maroua.

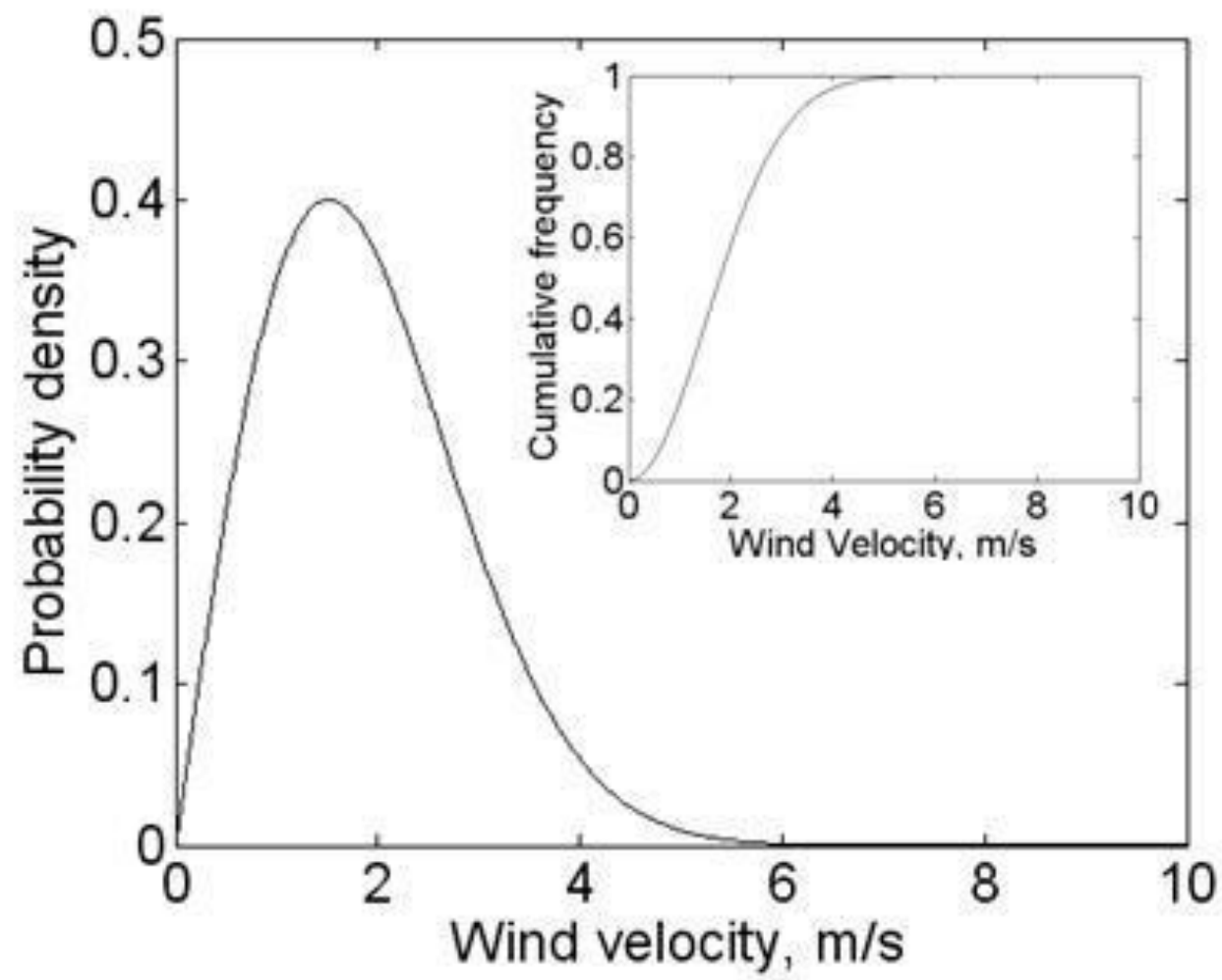

Fig-6. Rayleigh distribution of wind velocity at Bamenda and Bafoussam. 


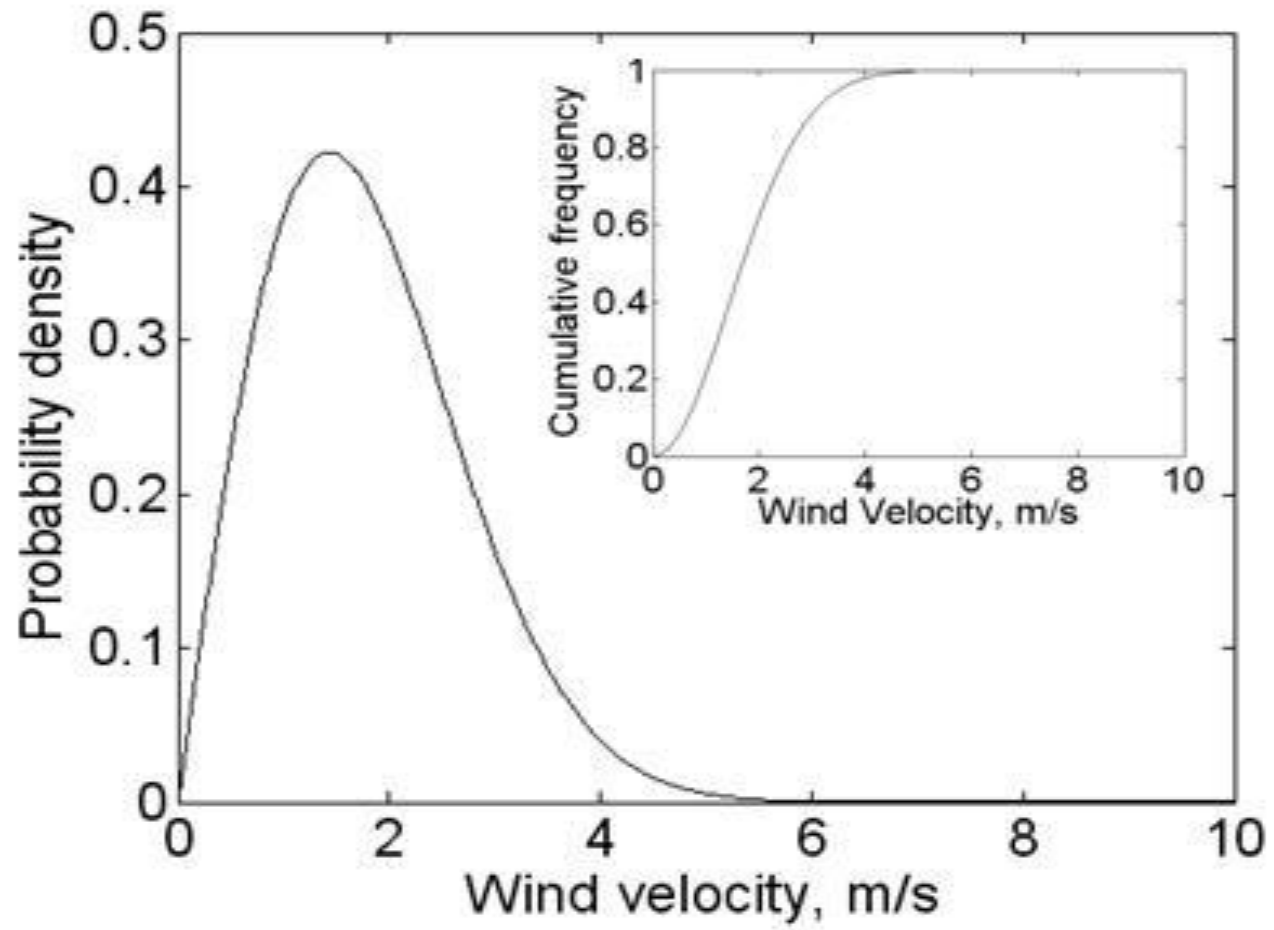

Fig-7. Rayleigh distribution of wind velocity at Douala and Fontem.

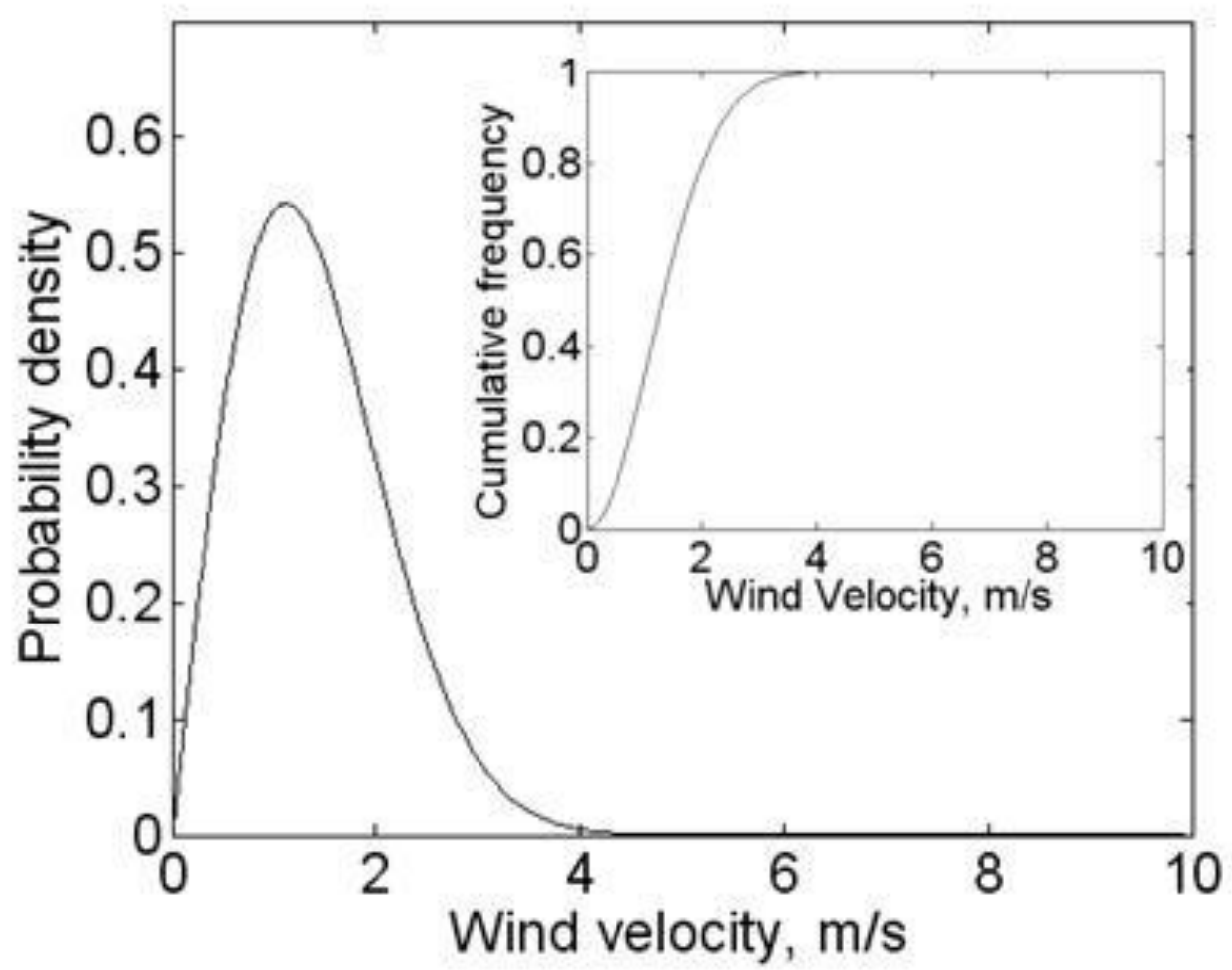

Fig-8. Rayleigh distribution of wind velocity at Ebolowa. 


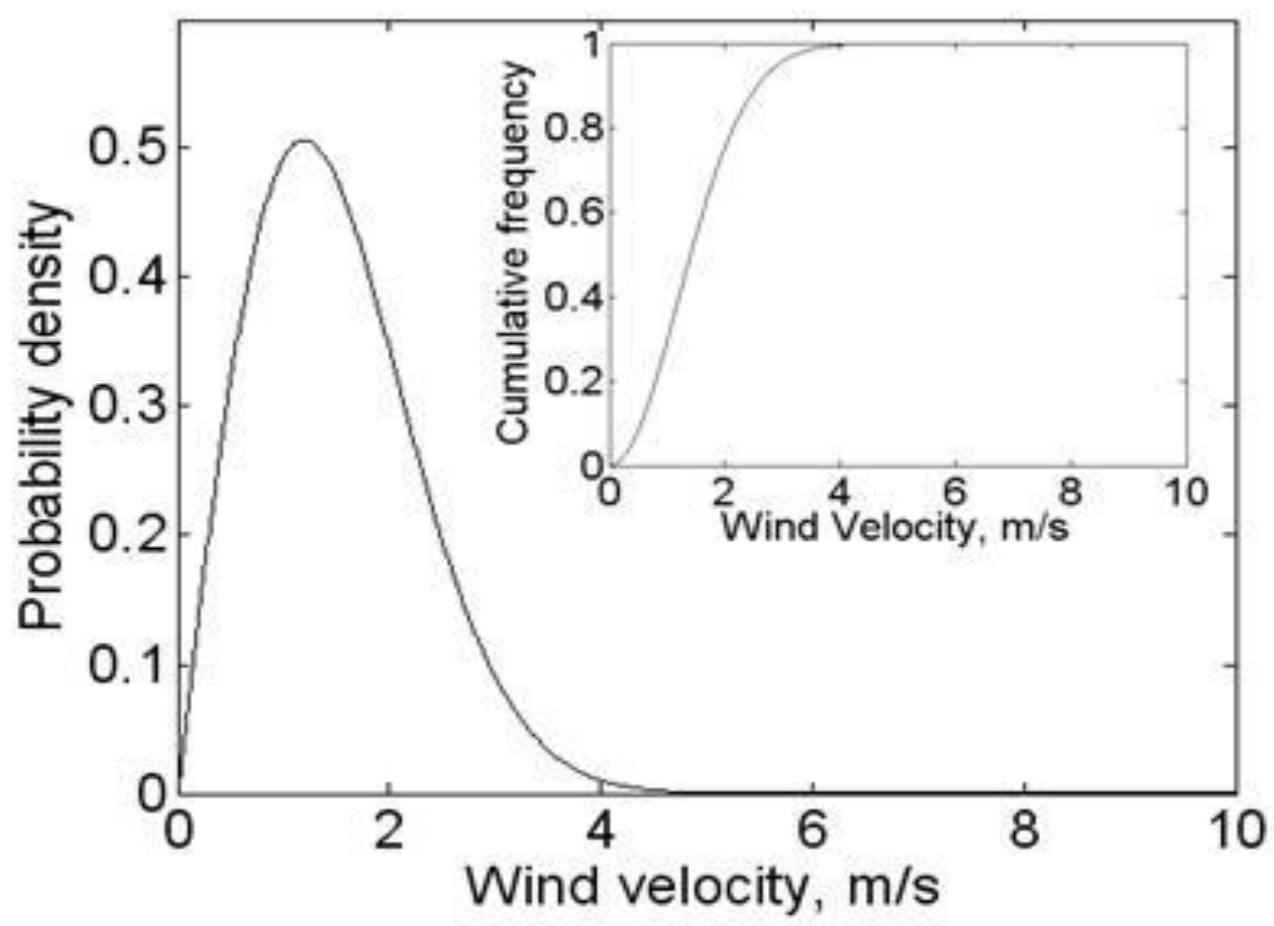

Fig-9. Rayleigh distribution of wind velocity at Yaounde.

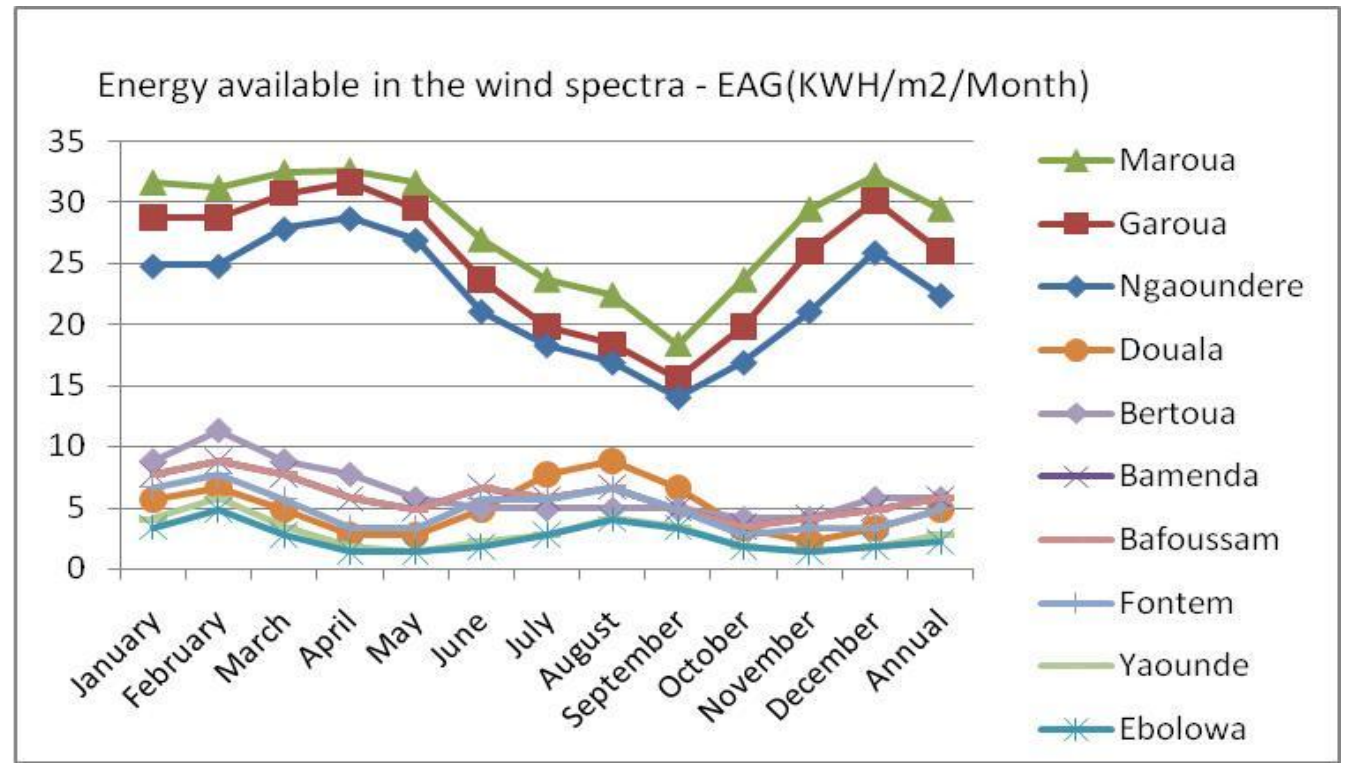

Fig-10. Energy available in the wind spectra 